\title{
Oppy and Modal Theistic Proofs
}

\author{
RichaRD DAVIS \\ Department of Philosophy \\ Tyndale University College \\ Toronto, Canada
}

I wish to thank Graham Oppy for clarifying his earlier attempt to "provide a general ground for objecting to all modal theistic arguments" by showing that any such argument "must be question-begging." In hindsight, Oppy now admits "it is not clear" that even his clarified argument is "acceptable as it stands." Nevertheless, he insists that my critique "fails to touch" that argument. In what follows, I show that Oppy's reasons for thinking so are spurious, since they are based upon (1) an unsuccessful attempt to show that theism and modal concretism are compatible, and (2) an account of begging the question which is entirely too permissive.

\section{I}

In "God and Modal Concretism," I pointed out that while a modal theistic proof (hereafter, MTP) will no doubt presuppose the falsity of Lewis's account of possible worlds, it does not follow (as Oppy asserts) that "it will rely on assumptions about the nature of logical space which can only be supported by the further claim that God actually exists." I began by making things harder for myself, presenting a series of reasons for thinking that "necessary being" theism $(T)$ is incompatible with modal concretism $(C)$ roughly, Lewis's idea that possible worlds are maximal physical objects, that modal property possession is to be defined in terms of counterpart theory, and so on. Here I was simply following Oppy's lead in assuming "that there

\footnotetext{
ABSTRACT: I argue that Graham Oppy's attempt to redefend his charge that all modal theistic arguments "must be question-begging" is unsuccessful. Oppy's attempt to show that theism and modal concretism are compatible is not only tangential for his purposes, it is marred by a misunderstanding of theism, and vulnerable to a counterexample that actually demonstrates incompatibility. Moreover, the notion of begging the question employed by Oppy against the theist is seen to be far too permissive.
}

1. See Graham Oppy, "Modal Theistic Arguments," Sophia 32 (1993): 18, 20.

2. See Graham Oppy, "Reply to Richard Davis," Philosophia Christi 11 (2009): 423-35.

3. Ibid., 423.

4. See my "God and Modal Concretism," Philosophia Christi 10 (2008): 57-74.

5. Oppy, "Modal Theistic Arguments," 20 (emphasis added). 
are just two different accounts of the nature of logical space between which we must choose - the account offered by Lewis, and the account offered by the theist." This is perhaps an oversimplification; still, as Oppy notes,

for the purposes of illustrating divergent conceptions of logical space, it seemed to me that there was an advantage in working with Lewis's modal realism simply because of the vivid picture that it presents of the metaphysics of modality. ${ }^{7}$

Agreed.

Now if $T$ and $C$ are incompatible - that is, if $\sim \diamond(T \& C)$ - it follows that $C \Rightarrow \sim T$. Relying upon $C$ in a theistic proof is therefore ill-advised, since it entails atheism. But of course $\sim \diamond(T \& C)$ also entails $T \Rightarrow \sim C,{ }^{8}$ which raises a different problem. Would it not then be a case of circular reasoning to assume $\sim C$ in an MTP? After all, $\sim C$ is an entailment of theism itself. The question is whether this is objectionable. And if so, how so? To complicate matters, I noted that there are different accounts of "circularity" on offer; indeed, there is serious and heated debate over which of these best explains why circular arguments should be classified as defective or fallacious. ${ }^{9}$ Unfortunately, while Oppy's 1993 paper includes the accusation of circularity, it fails to include any account of what he has in mind. I therefore explored various possibilities on his behalf, concluding that the problem could lie neither with logical or epistemic circularity; nor could it be due to Oppy Circularity (OC) - a malady of his own invention. I ended by briefly sketching an MTP immune to all of Oppy's criticisms. ${ }^{10}$

The crucial thing to see is that if theism and concretism are incompatible, that only makes the alleged circularity problem more acute. It is therefore something of a surprise to see Oppy disputing this incompatibility vigorously and at such length. If he is right, my job becomes all the easier (and his, I am afraid, all the harder). But is Oppy right? Well, I do not think so. Oppy's specific complaints focus on the arguments I gave to show that there is no way for God to exist in a Lewis world. There is no dispute here over this or that premise as one would expect. Rather, what Oppy wants to say is that while theism is inconsistent with Lewisean concretism $(C)$, it is perfectly compatible with concretism more broadly construed (call this " $C^{* \prime)}$ :

6. Oppy, "Modal Theistic Arguments," 20.

7. Oppy, "Reply to Richard Davis," 427.

8. I use the double-line arrow for entailment (i.e., for logically necessary material implication).

9. See Douglas Walton, "Epistemic and Dialectical Models of Begging the Question," Synthese 152 (2006): 237-84.

10. Oppy's only complaint with this proof is that it is not a modal ontological argument; for it does not include two key premises: (1) that if a being $S$ is possible, then $S$ is necessary, and (2) that $S$ is possible. This is disputable, but I do not have the space here to adequately deal with this objection. But see my more detailed presentation in "The Conceptualist Argument: A New Defense," unpublished. See also Quentin Smith, "The Conceptualist Argument for God's Existence," Faith and Philosophy 11 (1994): 38-49. 
If we combine theism with concretism, then it isn't true that worlds are maximal physical objects: rather, worlds are mereological sums, of which at most one part is a maximal physical object. Theists who agree with Davis that God might not have created will suppose that there is at least one possible world in which there is no physical part; theists who think that God could not have failed to create will suppose that there are no possible worlds that have no physical part. ${ }^{11}$

He then concludes that "Davis's arguments for inconsistency between theism and concretism fail."12 But this is a whopping non sequitur. What follows, at best, is only that my arguments fail to show that $T$ and $C^{*}$ are incompatible. But since that was no part of my project, it is hardly an objection. ${ }^{13}$ And this is all beside the point anyway; none of this even slightly advances Oppy's central claim that a theist's assumptions about modality "can only be supported" by presupposing theism. (You will notice that in his present contribution, this claim is dropped entirely.)

At any rate, how does merely announcing that worlds are mereological sums demonstrate or prove that $T$ and $C^{*}$ are compatible? Well, it does not by itself. So Oppy adds that God's existing necessarily can be understood in terms of his having a counterpart in each of these mereological sums. To say that God necessarily has his omni-properties means that "in each one of the worlds, the counterpart of God is omnipotent, omniscient, omnigood, eternal, and the creator of the world ex nihilo." ${ }^{14}$ Here we can safely ignore this idea that God necessarily creates, and that each world therefore has a maximal physical object (MPO) as a part. For this implies that God creates by the necessity of his nature, that creation is not the free act of a personal cause or agent, and that matter is logically necessary. Only Spinoza and his followers would dream of saying such things. ${ }^{15}$ This is no tenet of classical theism.

What about this idea that God has counterparts? What is that supposed to mean? What is a counterpart? The grandfather of counterpart theory, David Lewis, explains:

I prefer to say that you are in the actual world and no other, but you have counterparts in several other worlds. Your counterparts resemble you closely in content and context in important respects. ... But they are not really you. For each of them is in his own world, and only you are here in the actual world. ${ }^{16}$

11. Oppy, "Reply to Richard Davis," 431.

12. Ibid.

13. Oppy's "Modal Theistic Arguments" knows nothing of worlds as mereological sums, containing at most one maximal physical object as a part.

14. Oppy, "Modal Theistic Arguments," 18-19.

15. Thus saith Samuel Clarke. See his A Demonstration of the Being and Attributes of God and Other Writings, ed. Ezio Vailati (Cambridge: Cambridge University Press, 1998), 46.

16. David Lewis, "Counterpart Theory and Quantified Modal Logic," Journal of Philosophy 65 (1968): 114. 
Putting this together with Oppy's suggestion, what we must envision, I suppose, are distinct worlds each containing beings who possess the omni-properties, but who are not identical with each other or the God of the actual world. No doubt many of these worlds will have MPOs, and of course these too will be distinct. But at least one world will contain only a God counterpart.

For the sake of simplicity, then, let us imagine there are only three "mereological worlds":

(W1) $\mathrm{God}_{1}+\mathrm{MPO}_{1}$

(W2) $\mathrm{God}_{2}+\mathrm{MPO}_{2}$

(W3) $\mathrm{God}_{3}$

Notice that there is a God counterpart in each world; we have also got some worlds with MPO parts and others without. Doesn't this automatically show that $T$ and $C^{*}$ are compatible? By no means. First, if $\operatorname{God}_{1} \neq \operatorname{God}_{2} \neq \operatorname{God}_{3}$, then what we have is not "necessary being" theism, but rather a bizarre form of polytheism: multiple distinct omni-beings each existing in its own world.

Second, Lewis, Oppy, and the "necessary being" theist all hold that the nature and number of possible worlds is a matter of necessity. According to Lewis, for example, "it is not contingent what conditions the entire system of worlds does or does not satisfy." ${ }^{17}$ Oppy concurs: "the nature of logical space cannot be a contingent matter." 18 But if so, every possible world will exist as a matter of necessity, in which case (if Lewis is right) each of W1, $\mathrm{W} 2$, and W3 will have a counterpart in the others. But this is not possible. For one thing, W1 and W2 cannot have counterparts in W3 because W3 is an MPO-less world; as such, it cannot possibly contain (as a mereological part) an MPO resembling those in W1 and W2.

Furthermore, suppose $\mathrm{MPO}_{1}$ is as big as our cosmos, while $\mathrm{MPO}_{2}$ is quite small - perhaps only the size of a flea. ${ }^{19}$ Then it simply will not be possible for $\mathrm{MPO}_{2}$ to contain anything that closely resembles $\mathrm{MPO}_{1}$, from which it follows that W1 will not have a counterpart in W2. Anyway you look at it, Oppy's attempt to graft God into mereological worlds yields a contingent logical space; and this is not compatible with the modal framework required by "necessary being" theism. So it seems to me that Oppy's "add on" to Lewis's concretism is in serious trouble. Not only has Oppy failed to show how $T$ and $C^{*}$ are compatible, we can (I believe) see quite clearly that they are not.

17. David Lewis, On the Plurality of Worlds (Oxford: Basil Blackwell, 1986), 125.

18. Oppy, "Modal Theistic Arguments," 23.

19. Plantinga points out that on Lewis's definition of "maximal physical object," some Lewis worlds will be "no larger than a flea" (Alvin Plantinga, Essays in the Metaphysics of Modality, ed. Matthew Davidson (Oxford: Oxford University Press, 2003), 205). 


\section{II}

So we have this claim from Oppy that all MTPs are question-begging or circular. Well, how so? In what sense are they defectively circular? In a footnote, I briefly mentioned that it was not likely to be logical circularity that Oppy had in mind. For on his view, every valid argument is logically circular. ${ }^{20}$ Quoting William Rowe, Oppy tells us that logical circularity is present "when a premise in an argument, or a main conjunct of a premise, is identical to the conclusion." ${ }^{21}$ Here I simply noted for the record that a simple little argument like $(P \&(P \supset Q) \vdash Q$ is valid, but it is not logically circular on the definition; for its conclusion, $Q$, does not appear as either a premise or a main conjunct of a premise. So we have a clear-cut counterexample to the general principle.

Here Oppy attempts to redefend his claim that all valid arguments are logically circular. On what seems to be his favored approach to the matter, the argument goes as follows:

if the argument, $P_{1}, \ldots, P_{n}$ therefore $Q$, is valid, then the conjunction $\left(P_{1} \& \ldots \& P_{n}\right)$ is logically equivalent to the conjunction $\left(Q \&\left(P_{1} \&\right.\right.$ $\left.\left.\ldots \& P_{n}\right)\right)$. Since the argument, $\left(Q \&\left(P_{1} \& \ldots \& P_{n}\right)\right)$ therefore $Q$, is logically circular, we can then conclude that the argument, $P_{1}, \ldots, P_{n}$ therefore $Q$, is also logically circular. ${ }^{22}$

I have two observations. First, Oppy's argument appears to be deductively valid. But if so, then it must be logically circular; that is what the conclusion of the argument says. So Oppy has used a valid, logically circular argument to prove that all valid arguments are logically circular. And isn't that circular?

Secondly, the argument contains a false premise. Consider once again

(1) $(P \&(P \supset Q)) \vdash Q$.

(1) is indisputably valid; after all, it is modus ponens, everyone's favorite argument form. But then if Oppy is right, " $P \&(P \supset Q)$ " is logically equivalent to " $[P \&(P \supset Q)] \& Q$. ." And that is fair enough. But he then goes on to say that since

(2) $([P \&(P \supset Q)] \& Q) \vdash Q$

is logically circular, so is (1). But this inference is patently invalid; for while the premise of (2) has a main conjunct identical to the conclusion (namely, $Q$ ), this is manifestly not the case with (1). Its conclusion appears neither as

20. See Graham Oppy, Ontological Arguments and Belief in God (Cambridge: Cambridge University Press, 1995), 55.

21. Ibid., 54. The quotation from Rowe is from William Rowe, "Comments on Professor Davis' 'Does the Ontological Argument Beg the Question?"' International Journal for Philosophy of Religion 7 (1976): 443.

22. Oppy, "Reply to Richard Davis," 432. 
a premise nor a main conjunct of a premise. Hence it is not logically circular. Thus Oppy's argument fails. Just because (1) is logically equivalent to an argument that is logically circular, it does not follow that (1) is also inflicted with logical circularity.

Is the alleged circularity crippling all MTPs perhaps epistemic in nature? As Alston explains it, this defect occurs in an argument when we must presuppose its conclusion, in order to determine the truth of its premises, or be justified in accepting them. ${ }^{23}$ Here I showed how the theist need not rely upon theism itself in either rejecting concretism or adopting an alternative modal metaphysics. Notice that Oppy never disputes the point; he does not try to say that all MTPs are epistemically circular. He simply complains that on my account the argument $A \vdash A$ is "a question-begging argument if ever there was one, ${ }^{, 24}$ but it is not true that we must presuppose $A$ to be justified in accepting $A$. That is right. But Oppy has badly confused the issue. I am not defending an account of epistemic circularity. Nor am I claiming that all question-begging arguments are epistemically circular. Why would I have to do a thing like that? Perhaps I would have obligations of this sort, if I were the one claiming that all MTPs were question-begging. But of course that is no part of what I am doing. So Oppy's remarks here are well off the mark.

Finally, I explored the possibility that MTPs suffer from a very different sort of circularity-Oppy Circularity (OC):

[Suppose] that I am committed to a claim that $p$ as part of my perhaps tacit reasonable commitment to a broader consistent set of claims C. Suppose further that an opponent produces an argument of the form ' $Q_{1}, \ldots, Q_{n}$ therefore not $p$,' where the negations of one or more of the $Q_{i}$ are claims that belong to $C$. then that argument begs the question against me. Moreover, this is true even if I cannot provide a clear characterization of the set of claims $C .^{25}$

It seems to me that being circular in this sense is no strike against an argument at all. And in fact, Oppy concedes that “(OC) isn't quite right as a partial characterization of begging the question." ${ }^{\prime 26}$ Still, he thinks it has merit and chastises me for not saying what my reasons are for rejecting it: "It may be that Davis has good reasons for rejecting (OC). However, his telling us that he has such reasons doesn't make it so." ${ }^{\prime 27}$ No doubt. But I am afraid Oppy has taken the bait. Why this request for good clear reasons? (OC) does not mention needing anything like that. It only says that you have begged the question against me if you present me with an argument whose premises contradict things I am reasonably committed to. But this is altogether too

23. See William Alston, "Epistemic Circularity," Philosophy and Phenomenological Research 67 (1986): 10.

24. Oppy, "Reply to Richard Davis," 433.

25. Oppy, Ontological Arguments and Belief in God, 56.

26. Oppy, "Reply to Richard Davis," 435.

27. Ibid. 
easy. On this account, far too many arguments will turn out to be questionbegging. Indeed, as I pointed out, we can easily imagine a critic bringing this very same charge against Oppy upon being presented with $(\mathrm{OC}) .^{28}$

What is Oppy's response? Although (OC) says that the charge sticks even if the critic "cannot provide a clear characterization" of her reasons, Oppy will not have it. He insists on knowing whether the premises advanced by his critic are really good reasons - presumably, better reasons than his own. And that, I think, is actually the right thing to say. But it is said much too late in the game. The lesson to be learned is that I do not beg any questions against you by merely presenting you with premises that contradict things you are reasonable in believing given your other commitments. For it may be that you ought to accept my premises, since they are more reasonable than your own. (Not all reasonable premises are created equal.) In cases like this, I submit, there are no questions begged at all. I only wish Oppy had adopted this dialectical mind-set from the start, and had provided us with a clear set of good reasons for thinking that all MTPs are question-begging. Unfortunately, so far as I can see, not only were the reasons not good, they were never really given.

28. This is especially likely since there is a current split between two rival hypotheses in the literature on begging the question: the epistemic theory (based on knowledge and belief) and the dialectical theory (based on commitment and dialogue). (OC) is a species of the latter, and is by no means lacking in critics whose reasonable commitments are contradicted by (OC)'s implicit premises. For further details, see Walton, "Epistemic and Dialectical Models of Begging the Question," 237-84. 